\title{
Zekere zekerheid
}

\section{Het belang van zekere zekerheid voor de financiering van het bedrijfsleven}

\author{
Prof. mr. drs. F.E.J. Beekboven van den Boezem en \\ $m r \cdot R \cdot \operatorname{van} d e n \quad B o s c b^{*}$
}

\begin{abstract}
1 Inleiding
In de kredietbehoefte van het bedrijfsleven wordt voor het grootste deel voorzien door banken. Tot zekerheid voor de nakoming van de verplichtingen van de kredietnemers zijn de financieringen die zij verstrekken voor een groot deel afgedekt met goederenrechtelijke zekerheidsrechten. Het gaat daarbij vooral om pandrechten op vorderingen, voorraad en inventaris en hypotheekrechten op registergoederen. ${ }^{1}$ Die zekerheidsrechten zijn niet alleen van belang voor het antwoord op de vraag hoeveel een bank van de door haar uitgeleende gelden terugziet in het onverhoopte geval dat zij tot het opzeggen van de kredietovereenkomst en het uitwinnen van de zekerheden moet overgaan. Zij spelen al eerder een financiële rol, in die zin dat zij (mede) het kapitaal bepalen dat een bank moet aanhouden ten opzichte van de lening die zij verstrekt. Voor leningen die worden gedekt door een recht van pand of hypotheek behoeft namelijk minder kapitaal te worden aangehouden ter dekking van het kredietrisico dan zonder die zekerheidsrechten het geval zou zijn. ${ }^{2}$ Leningen waarvoor de bank geen kapitaal hoeft aan te houden, zijn natuurlijk goedkoper dan leningen waarvoor dit wel het geval is. Maar wil een goederenrechtelijke zekerheid tot een werkelijke verlaging van het kapitaalsbeslag leiden, dan moet zeker zijn dat die zekerheid zeker is, in die zin dat vaststaat dat (1) hetgeen waarop het zekerheidsrecht moet worden gevestigd als 'goed' bestaat, (2) het betreffende goed voor het erop vestigen van een zekerheidsrecht vat-
\end{abstract}

* Prof. mr. drs. F.E.J. Beekhoven van den Boezem is juridisch adviseur ING, hoogleraar onderneming en financiering aan de Radboud Universiteit Nijmegen, raadsheer-plaatsvervanger in het Gerechtshof's-Hertogenbosch en rechter-plaatsvervanger in de Rechtbank Noord-Nederland. Mr. R. van den Bosch is bedrijfsjurist bij ING.

1. Over het boekjaar 2014 stond er binnen ING bijv. wereldwijd een bedrag uit van $€ 517.478 .000 .000$. Beperkt tot Nederland ging het om een bedrag van $€ 206.422 .000 .000$. Van dit bedrag was ruim $65,5 \%$ hypothecair gedekt. Van het buiten Nederland uitstaande bedrag van $€ 311.056 .000 .000$ was ruim $48 \%$ hypothecair gedekt. Boven op de genoemde hypothecaire dekkingspercentages is een substantieel deel van de uitgeleende gelden gesecureerd door pandrechten op (voornamelijk) voorraden, vorderingen en overig roerend actief. Deze gegevens zijn ontleend aan de openbare jaarcijfers van ING over het jaar 2014.

2. Het moet gaan om zogenaamde 'toelaatbare zekerheden'. Zie daarover Verordening (EU) 575/2013 van het Europees Parlement en de Raad van 26 juni 2013 betreffende prudentiële vereisten voor kredietinstellingen en beleggingsondernemingen en tot wijziging van Verordening (EU) 648/2012, (kortweg: Capital Requirements Regulation (CRR)), art. 92 lid 3a en 197-199. baar is, (3) aan de vestigingsvereisten voor het zekerheidsrecht is voldaan, en (4) het in zekerheid gegeven goed eenvoudig kan worden uitgewonnen. Een bank is er dus veel aan gelegen om over deze punten duidelijkheid te krijgen; rechtsonzekerheid is in dit geval immers kostbaar. Vandaar dat er de afgelopen jaren enkele (proef)procedures zijn gevoerd over deze vier punten, veelal in Nederlandse Vereniging van Banken-verband. In deze bijdrage geven wij daarvan een overzicht.

\section{Werkkapitaalfinancieringen op borrowing base}

Niet over elke uitgezette euro hoeft per definitie een vast percentage kapitaal te worden aangehouden. Of en in welke mate dit het geval is, hangt onder meer af van het door de betreffende bank gebruikte model voor de berekening van het kredietrisico en het antwoord op de vraag of er door de kredietnemer of een derde goederenrechtelijke en/of persoonlijke zekerheidsrechten zijn gesteld waarvan het kredietrisicolimiterende effect door de regelgeving wordt erkend. Daarnaast is de kwaliteit van de kredietnemer natuurlijk van belang. Wordt een lening bijvoorbeeld afgedekt door een garantie van een overheid met een goede rating, dan hoeft de bank minder geld voor die lening aan te houden. Ditzelfde is het geval als een bank goederenrechtelijke dekking (een (eerste) recht van pand of hypotheek) van de kredietnemer of een derde heeft verkregen op 'toelaatbare zekerheden'. Voor zogenaamde 'blanco' leningen, dat wil zeggen leningen waarvoor geen goederenrechtelijke of persoonlijke zekerheidsrechten zijn gesteld, dient de bank een mede van de gegoedheid van de kredietnemer afhankelijk gesteld percentage van het uitgeleende bedrag aan te houden. Kortom: naarmate het risico voor de bank toeneemt, dient zij een stapsgewijs groter wordend bedrag aan kapitaal aan te houden. Aan de hand van een werkkapitaalfinanciering op basis van een zogenaamde borrowing base kan een en ander mooi worden geillustreerd.

Bedrijven hebben te maken met wisselende liquiditeitsposities en -behoeften. Werkkapitaalfinancieringen voorzien hierin. Een bedrijf krijgt hierbij een bepaalde kredietlimiet toegewezen, waarbinnen op verschillende manieren kan worden beschikt. Zo kunnen vaste leningen worden opgenomen voor de verwerving van een object (bijvoorbeeld een machine) of de aandelen in een te verwerven vennootschap. Ook kunnen 
bankgaranties worden gesteld, of worden in het kader van het grensoverschrijdend betalingsverkeer accreditieven of letters of credit geopend. Een belangrijke aanwending van werkkapitaalfinancieringen is verder het creëren van bestedingsruimte in rekening-courant.

Voor zover werkkapitaalfinancieringen worden aangewend voor de financiering van voorraden en vorderingen, vindt financiering in de regel plaats op een zogenaamde borrowing base. Dit betekent dat het bedrag dat een financier bereid is in de vorm van een krediet te verstrekken, direct afhankelijk is van de waarde van de activa in kwestie, te weten de voorraden en vorderingen. Op deze activa dient vervolgens een pandrecht tot stand te komen. Bij financieringen die verondersteld worden te zijn gedekt door een pandrecht op voorraden en vorderingen mag geen ruimte zijn voor twijfel aan de hardheid en uitwinbaarheid van de dekking. ${ }^{3}$ Dit geldt vanzelfsprekend bij afwikkeling van het krediet gevolgd door uitwinning van de zekerheidsrechten, alleen al omdat ook de bank zelf in staat moet zijn om met het daarmee teruggekregen geld degenen terug te betalen bij wie zij het geld (inclusief rente) had ingeleend. Een onbetrouwbare borrowing base, in die zin dat niet duidelijk is of het pandrecht op de activa correct is gevestigd en zonder problemen kan worden uitgewonnen, heeft echter niet alleen consequenties voor wat betreft de afwikkeling van het krediet. De gevolgen hiervan dienen zich al in een veel eerder stadium aan, te weten bij de bepaling van het door de bank aan te houden kapitaal. Hiervoor werd al gewezen op het feit dat minder kapitaal hoeft te worden aangehouden op uitgeleende bedragen die zijn gedekt door een recht van pand of hypotheek. Juist bij werkkapitaalfinancieringen die zijn gebaseerd op een borrowing base wordt de hoogte van het krediet immers direct afhankelijk gesteld van de waarde van het actief dat met de financiering wordt verworven. Als het pandrecht van de bank op dit actief twijfelachtig wordt, dan is de consequentie daarvan dat het pandrecht niet mag worden meegenomen in de berekening van het aan te houden kapitaal en er dus meer kapitaal moet worden aangehouden. De risicovergoeding moet daarmee omhoog, waarmee de prijsstelling van de lening verandert. In het uiterste geval leidt een en ander ertoe dat de bank moet besluiten dergelijke financieringen niet langer beschikbaar te stellen.

\section{3 (Proef)procedures voor zekere zekerheid}

Hiervoor zagen we dat cruciaal is dat een bank moet kunnen vertrouwen op de hardheid, houdbaarheid, uitwinbaarheid en dus de waarde van de gestelde zekerheden: zekerheid moet zeker zijn. Als daarover op enig moment twijfel is, ontstaat direct een probleem. Niet pas op het moment dat de betreffende zekerheidsrechten zouden moeten worden uitgewonnen omdat de kredietnemer zijn verplichtingen uit de financieringsovereenkomst niet nakomt, maar direct, ook als de kredietnemer zijn verplichtingen uit de financieringsovereenkomst netjes nakomt, omdat de bank dan meer kapitaal voor

3. Zie art. 194 CRR. de betreffende lening moet aanhouden. Dit laatste is een kostbare zaak, ook voor de kredietnemer, omdat de bank de toename in de risicokosten zal willen doorberekenen in de prijsstelling van het krediet. Reden waarom banken de afgelopen jaren verschillende (proef)procedures hebben gevoerd over de vraag (1) of hetgeen in zekerheid moet worden gegeven bestaat als 'goed', (2) of het betreffende goed zich leent voor het vestigen van een zekerheidsrecht daarop, (3) of met eenvoudige formaliteiten aan de wettelijke vestigingsvereisten is voldaan, en (4) of praktische uitwinning van de zekerheidsrechten strookt met de wettelijke voorschriften daarvoor.

\section{Ad 1. Bestaat hetgeen in zekerheid moet worden gegeven als 'goed'?}

Vooraleer men toekomt aan de vraag of de vestiging van het zekerheidsrecht geldig is, moet de vraag worden beantwoord of hetgeen waarop die vestiging dient plaats te vinden, kwalificeert als 'goed' in de zin van art. 3:1 van het Burgerlijk Wetboek (BW), en - zo ja - of het goed op dat moment überhaupt bestaat. Een zekerheidsrecht op iets dat geen 'goed' is in de zin van de wet, of nog niet bestaat, is immers niet mogelijk. De vraag naar de kwalificatie als 'goed' doet zich bijvoorbeeld voor ten aanzien van assurantieportefeuilles en overige portefeuilles met orders, bijvoorbeeld van een makelaar. Via een prejudiciële procedure bij de Hoge Raad heeft men getracht antwoord te krijgen op de vraag of een assurantieportefeuille een vermogensrecht is in de zin van art. 3:6 BW, en daarmee een goed in de zin van art. 3:1 BW. Vooralsnog heeft de Hoge Raad die vraag niet willen beantwoorden. ${ }^{4}$ Omdat dit een voorvraag is voor verpanding, tast de financiële praktijk dus nog in het duister over de verpandbaarheid van dergelijke portefeuilles. Dit klemt temeer waar zo'n portefeuille vaak het enige waardevolle actief van een bemiddelaar is om in zekerheid te geven.

De problematiek van het al dan niet bestaan van hetgeen in zekerheid moet worden gegeven, doet zich voor wanneer het in zekerheid te geven goed een vordering betreft. De vraag naar het ontstaansmoment van vorderingsrechten blijft een moeilijke, en ook de rechtspraak worstelt ermee. Want waar ligt precies de scheidslijn tussen het ontstaansmoment van het

4. Rb. Rotterdam 13 maart 2013, HA ZA 12-2163, 13/02008, ECLI:NL:RBROT:2013:BZ4891, Rb. Rotterdam 17 april 2013, ECLI:NL:RBROT:2013:BZ8347 en HR 31 mei 2013, ECLI:NL:HR: 2013:CA1614, NJ 2013/321 m.nt. A.I.M. van Mierlo, JOR 2013/228 m.nt. A. Steneker (Van der Geest/Butin Bik q.q. en Duymel Assurantien). In jurisprudentie en literatuur wordt de onderhavige vraag verschillend beantwoord. Bevestigend: Rb. Roermond 5 oktober 2012, JOR 2012/309 m.nt. A. Steneker (Nedasco/Rabobank, Vostro Denaro en Vault), F.J.L. Kaptein, Het portefeuillerecht als vermogensrecht van de assurantietussenpersoon: overdracht, en executie door de pandhouder, TvI 2011/22 en F.J.L. Kaptein, Naschrift op: Verpanding van verzekeringsportefeuilles anders belicht, TvI 2011/30; en Steneker, Pandrecht (Mon. BW) 2012/65 en zijn annotatie onder de hiervoor genoemde uitspraak van de Rechtbank Roermond. Anders: G.H.G.M. van Berkel, Verpanding van verzekeringsportefeuilles anders belicht, TvI 2011/29; en A.J. Verdaas, Pandrecht op een assurantieportefeuille?, FIP 2013, p. 24-29, die meent dat de portefeuille als zodanig niet vatbaar is voor verpanding, maar wel de vorderingen die ervan deel uitmaken. 
vorderingsrecht en het opeisbaar worden ervan? En wanneer moet een vordering worden gekwalificeerd als een bestaande voorwaardelijke vordering in plaats van een relatief toekomstige (dat wil zeggen een vordering die nog niet bestaat, maar wel voortkomt uit een op dat moment bestaande rechtsverhouding)? Voor financiers zijn de antwoorden op die vragen van groot belang, omdat slechts op bestaande (eventueel voorwaardelijke) vorderingen een pandrecht kan worden gevestigd. Gaat het om relatief toekomstige vorderingen, dan kan weliswaar de vestigingshandeling voor een pandrecht daarop reeds voor het moment van ontstaan van de vorderingen worden verricht, maar komt het pandrecht pas tot stand op het moment dat de vorderingen werkelijk in het vermogen van de pandgever ontstaan. Zou tussen het moment van de vestigingshandeling en het moment van het daadwerkelijk ontstaan van de vordering de pandgever failleren, dan komt het pandrecht niet tot stand.

De problematiek van het verschil tussen het ontstaan van de vordering en het opeisbaar worden ervan kwam recentelijk weer eens aan de orde in de zaak FA-MED/Kreikamp q.q. ${ }^{5}$ FA-MED en de curator verschilden van mening over het ontstaansmoment van vorderingen van een zorgaanbieder op een zorgverzekeraar uit hoofde van onderhanden werk. FA-MED stelde zich op het standpunt dat die vorderingen ontstonden bij aanvang van de behandeling van de patiënten - welk moment vóór faillissement lag - en zij op die vorderingen pandrechten had. De curator meende dat dit niet het geval was, omdat de betreffende vorderingen pas zouden ontstaan op het moment dat de behandeling van de patiënten was afgerond en volledig geadministreerd en gevalideerd, in casu tijdens faillissement. De rechtbank gaf FA-MED gelijk, waar zij overweegt:

'4.10 De vordering van Better Life op de zorgverzekeraars ontstaat door het sluiten van een geneeskundige behandelingsovereenkomst tussen de zorgaanbieder en de (verzekerde) patiënt (althans steeds wanneer ter uitvoering van die behandelingsovereenkomst een medische behandeling is verricht).' (curs. FBvdB \& RvdB)

Op een dergelijke vordering kan een bank dus financieren, maar de gecursiveerde passage van deze overweging is ons inziens verwarrend. Tenzij partijen anders overeenkomen, dient immers te worden aangenomen dat met het aangaan van de overeenkomst de vorderingen daaruit direct ontstaan. Of aan de behandelingsovereenkomst reeds een begin van uitvoering was gegeven, is ons inziens slechts van belang voor de vraag naar de opeisbaarheid van de betreffende vordering. Voor de vraag of de betreffende vordering was verpand, is het moment van opeisbaarheid echter niet relevant. 5. Rb. Amsterdam 15 april 2015, zaak/rol C/13/564803 / HA ZA 14-490
(niet gepubliceerd).

6. HR 3 december 2010, JOR 2011/63 m.nt. B.A. Schuijling.
Het arrest van de Hoge Raad inzake ING/Nederend q.q. ${ }^{6}$ heeft duidelijkheid gegeven voor wat betreft de vraag wanneer een contractueel overeengekomen restitutievordering - te weten een vordering tot terugbetaling van hetgeen is overeengekomen, maar waarvoor als gevolg van opzegging door de curator geen tegenprestatie heeft plaatsgevonden - ontstaat. ${ }^{7}$ De Hoge Raad vindt de opzegging zo'n wezenlijk vereiste voor het ontstaan van de restitutievordering, dat die vordering pas daarmee ontstaat. $\mathrm{Nu}$ de opzegging pas plaatsvond door de curator in faillissement, heeft het pandrecht erop dus niet meer kunnen ontstaan bij gebrek aan beschikkingsbevoegdheid van de pandgever (art. 23 en 35 lid 2 van de Faillissementswet, Fw). Hetzelfde geldt voor de kwalificatie van de regresvordering die een hoofdelijk schuldenaar op zijn medeschuldenaren heeft voor hetgeen hij de schuldeiser meer betaalt dan waartoe hij in de interne verhouding tot zijn medeschuldenaren is verplicht. Met de uitspraak van de Hoge Raad in de zaak ASR c.s./Achmea werd duidelijk dat, anders dan wel werd aangenomen naar aanleiding van eerdere jurisprudentie van de Hoge Raad, die vordering niet gekwalificeerd moet worden als een bestaande, voorwaardelijke vordering, maar als een (relatief) toekomstige. ${ }^{8}$ Betaalt de hoofdelijk schuldenaar de schuldeiser in faillissement, dan kan op de eventuele regresvordering die dan het leven ziet dus geen pandrecht meer ontstaan. Deze uitspraak is van belang voor de financieringspraktijk, omdat dergelijke vorderingen tot aan deze uitspraak werden geacht reeds voorwaardelijk te bestaan en bancaire risico's werden afgedekt via verpanding ervan. ${ }^{9}$

\section{Ad 2. Kan op het goed een zekerheidsrecht worden gevestigd?}

De vraag of op een goed een zekerheidsrecht kan worden gevestigd, deed zich de afgelopen jaren bijvoorbeeld voor waar het de verpanding betrof van vorderingen ten aanzien waarvan partijen een cessie- of verpandingsverbod waren overeengekomen. Het gaat dan om bepalingen die veel voorkomen in algemene (inkoop)voorwaarden en luiden in de trant van: 'Het is de schuldeiser verboden de vordering over te dragen aan een derde.' Naar aanleiding van een verkeerde uitleg van het Oryx/ Van Eesteren-arrest van de Hoge Raad ${ }^{10}$ werd in de literatuur en lagere rechtspraak veelal aangenomen dat dergelijke bepalingen in principe goederenrechtelijke werking hadden, in die

7. Zie daarover, en over rechtsgevolgen van opzegging van duurovereenkomsten in het algemeen, F.E.J. Beekhoven van den Boezem \& R.J. van der Weijden, Rechtsgevolgen van opzegging van duurovereenkomsten, in: N.E.D. Faber, J.J. van Hees \& N.S.G.J. Vermunt (red.), Overeenkomsten en insolventie (Serie Onderneming en recht, deel 72), Deventer: Kluwer 2012, p. 49-62.

8. HR 6 april 2012, JOR 2014/172 m.nt. N.E.D. Faber en N.S.G.J. Vermunt (ASR c.s./Achmea).

9. Daarnaast is de problematiek van het ontstaansmoment van de regresvorderingen in de financieringspraktijk actueel bij discussies over de houdbaarheid van zogenaamde wederzijdse-zekerhedenarrangementen. Daarover worden op dit moment twee proefprocedures gevoerd (Rb. Amsterdam 27 augustus 2014, ECLI:NL:RBAMS:2014:5717 (ING CF/ Ingwersen q.q.) en Rb. Midden-Nederland 8 oktober 2014, JOR 2015/24 m.nt. N.E.D. Faber (DLL/Van Logtesteijn q.q.)).

10. HR 17 januari 2003, NJ 2004/281 m.nt. H.J. Snijders, JOR 2003/52 m.nt. M.H.E. Rongen. 
zin dat er op een vordering ten aanzien waarvan schuldeiser en schuldenaar zo'n beding hadden gemaakt, geen pandrecht kon worden gevestigd omdat de betreffende vordering door partijen onoverdraagbaar was gemaakt (art. 3:83 lid 2 BW). Voor het vestigen van een pandrecht vereist de wet immers dat de vordering waarop het pandrecht moet worden gevestigd overdraagbaar is (art. 3:81 en 3:228 BW). ${ }^{11}$ In voornoemd arrest stelde de Hoge Raad echter helemaal niets over de uitleg van dergelijke bedingen in het algemeen, maar gaf hij aan welk element in de weg stond aan verpanding in de situatie dat in lagere instantie was uitgemaakt dat een beding zoals hiervoor geciteerd in de gegeven omstandigheden moest worden uitgelegd als een onoverdraagbaarheidsbeding in de zin van art. 3:83 lid $2 \mathrm{BW} .{ }^{12}$ Dan was het niet de beschikkingsonbevoegdheid van de pandgever, maar de onoverdraagbare inhoud van de vordering die aan verpanding in de weg stond, aldus - terecht - de Hoge Raad. Dat wil natuurlijk niet zeggen dat dergelijke bedingen - ook wel cessie- of verpandingsverboden genoemd - in het algemeen goederenrechtelijke werking hebben. Steeds zal door uitleg moeten worden vastgesteld of dergelijke verboden gekwalificeerd moeten worden als onoverdraagbaarheidsbedingen in de zin van art. 3:83 lid 2 BW - in welk geval zij goederenrechtelijke werking hebben -, dan wel als bedingen waarvan schending niet meer dan wanprestatie oplevert - in welk geval zij dus niet meer dan verbintenisrechtelijke werking hebben. Omdat over de uitleg van cessie- en verpandingsverboden in de praktijk veel onduidelijkheid bestond, is de problematiek vorig jaar aan de Hoge Raad voorgelegd in de zaak Coface/Intergamma. In die procedure overwoog de Hoge Raad:

'3.4.2. Een beding als het onderhavige, dat naar zijn aard mede is bestemd om de rechtspositie te beïnvloeden van derden die de bedoeling van de contracterende partijen niet kennen, en dat ertoe strekt hun rechtspositie op uniforme wijze te regelen, dient te worden uitgelegd naar objectieve maatstaven, met inachtneming van de Haviltexmaatstaf (zie HR 20 februari 2004, ECLI:NL:HR: 2004:AO1427, NJ 2005/493). Als uitgangspunt bij de uitleg van bedingen die de overdraagbaarheid van een vorderingsrecht uitsluiten, moet worden aangenomen dat zij uitsluitend verbintenisrechtelijke werking hebben, tenzij uit de - naar objectieve maatstaven uit te leggen - formulering daarvan blijkt dat daarmee goederenrechtelijke wer-

11. Zie bijv. Rb. Maastricht 2 februari 2011, JOR 2012/231 (Rabobank/ Muurmans q.q.), Rb. Arnhem 19 december 2012, JOR 2013/219 m.nt. A. Steneker (PMTG Bergharen/Plusenergy) en Hof Arnhem-Leeuwarden 3 mei 2013, JOR 2013/154 m.nt. G.J.L. Bergervoet (Summertime Holding/Stichting Portaal).

12. Dit uitgangspunt vormde geen onderdeel van de in cassatie voorgelegde rechtsvragen. king als bedoeld in art. 3:83 lid 2 BW is beoogd. Het hof heeft dit miskend.'13

Deze uitkomst is voor de banken van groot belang, omdat veel vorderingen die zij in pand krijgen van een dergelijk beding zijn voorzien. Had de Hoge Raad geoordeeld dat dergelijke bepalingen in principe goederenrechtelijke werking hebben, dan zou een groot aantal pandrechten op grond van art. 3:228 $\mathrm{BW}$ niet tot stand zijn gekomen. Hiermee zou een groot aantal financieringen ongedekt zijn. Los van de vergaande implicaties bij afwikkeling in geval van verzuim aan de zijde van de kredietnemer, zou daarvoor bovendien dan direct meer kapitaal moeten worden aangehouden. Dit zou zich in elk geval hebben vertaald in een aanzienlijk hogere prijsstelling, maar de consequenties zouden veelal verder gaan dan dat: banken zouden er op grote schaal toe overgaan deze op de eerder geschetste borrowing base gebaseerde financieringen niet langer te verstrekken.

Omdat derden - in casu banken - de vraag of zij op dergelijke vorderingen kunnen financieren niet anders zullen kunnen beantwoorden dan aan de hand van de tekst van het betreffende beding waarbij zij zelf geen partij waren, koos de Hoge Raad voor objectieve uitleg als uitgangspunt. Dat lijkt ons, in ieder geval waar het gaat om business-to-business-geldvorderingen tussen professionele partijen, terecht. Van hen mag toch worden verwacht dat zij in staat zijn op te schrijven wat zij bedoelen, dan wel dat zij zich door deskundigen laten bijstaan zo dit niet het geval is. ${ }^{14}$ Jammer is dat toch ook de Hoge Raad de begrippen 'cessieverbod' en 'onoverdraagbaarheidsbeding' in deze passage even door elkaar lijkt te halen; anders dan cessieverboden hebben bedingen die de overdraagbaarheid van een vorderingsrecht uitsluiten - dat wil zeggen werkelijke art. 3:83 lid 2-bedingen - ons inziens immers per definitie goederenrechtelijke werking. Dit lijkt echter een slip of the pen, want de bedoeling van de Hoge Raad is duidelijk: is het beding geformuleerd als een eigenschap van de vordering, dan staat goederenrechtelijke werking bij de uitleg voorop. Is daarentegen de rechthebbende op de vordering het grammaticale onderwerp van de bepaling, dan is verbintenisrechtelijke werking het startpunt van uitleg.

Ad 3. Is aan de wettelijke vestigingsvereisten voldaan? Staat vast dat we met een 'goed' in de zin van art. 3:1 BW te maken hebben en dat dit goed overdraagbaar is (art. 3:83, 3:81 en 3:228 BW), dan zal een beperkt zekerheidsrecht daarop tot

13. HR 21 maart 2014, ECLI:NL:HR:2014:682, JOR 2014/151 m.nt. B.A. Schuijling, NJ 2015/167 m.nt. H.J. Snijders (Coface/Intergamma), inmiddels gevolgd door bijv. Hof Amsterdam 7 april 2015, C/13/499976 / HA ZA 11-2509 (Van der Schee q.q./ING) (niet gepubliceerd) en Rb. Oost-Brabant 15 april 2015, ECLI:NL:RBOBR: 2015:2179 (Bentfort van Valkenburg q.q./Van Lanschot).

14. Zie over de uitleg van cessieverboden uitgebreid F.E.J. Beekhoven van den Boezem \& G.J.L. Bergervoet, Uitleg van cessieverboden, TvI 2012/13 en over onoverdraagbaarheidsbedingen in het algemeen F.E.J. Beekhoven van den Boezem, Onoverdraagbaarheid van vorderingen krachtens partijbeding (diss. Groningen), Deventer: Kluwer 2003. 
stand komen als aan de vestigingsvereisten daarvoor is voldaan (art. 3:84 jo. art. 3:98 BW). Waar het roerende zaken betreft, gaat het in de praktijk meestal om een vuistloos pandrecht. De kredietnemer heeft immers zijn aan de bank verpande voorraad en inventaris nodig in het bedrijfsproces. Gaat het om vorderingen, dan is er in het algemeen eveneens sprake van een pandrecht dat tot aan het moment van mededeling aan de schuldenaar van de vordering niet naar buiten kenbaar is. De ondernemer wil namelijk vaak liever niet dat derden weten dat hij geld nodig heeft. Ook de bank doet, gelet op de administratieve rompslomp die dit met zich brengt, liever geen mededeling van het pandrecht aan debiteuren als dit nog helemaal niet nodig is, en wellicht helemaal nooit nodig zal zijn, omdat de kredietnemer zijn verplichtingen uit de kredietovereenkomst netjes nakomt.

De bank zal met name een vuistloos pandrecht willen vestigen op de toekomstige goederen van de kredietnemer, dat wil zeggen goederen die de ondernemer pas later in eigendom krijgt. Het pandrecht dient immers tot zekerheid voor het onverhoopte geval dat de kredietnemer in de toekomst niet aan zijn verplichtingen jegens de bank kan voldoen. Heeft de bank dat vertrouwen aan het begin al niet, dan dient zij natuurlijk af te zien van financiering in plaats van zekerheden te vestigen. Het gaat dus om een pandrecht op goederen die zich bij de kredietnemer bevinden op het moment dat hij zijn verplichtingen uit de financieringsovereenkomst niet nakomt. Veel van de goederen die aanwezig waren op het moment van het sluiten van de kredietovereenkomst zullen dan zijn verwerkt (grondstoffen), verkocht (voorraad), afgeschreven en vervangen (bedrijfsuitrusting) of afbetaald (vorderingen), waardoor het pandrecht (de facto) is tenietgegaan. Met het opmaken van één enkele akte op het moment van het sluiten van de kredietovereenkomst en het registreren daarvan kan de vestigingshandeling plaatsvinden voor het vuistloze pandrecht op alle huidige (art. 3:237 BW) én toekomstige zaken van de kredietnemer (art. 3:97-98 en 3:237 BW). Het ontstaan van het pandrecht op die laatste categorie is vanaf dat moment nog slechts afhankelijk van het intreden van de beschikkingsbevoegdheid van de kredietnemer daarover, te weten het moment dat hij die zaken in eigendom verwerft (vooropgesteld dat hij op dat moment niet failliet is).

Is het vestigen van een vuistloos pandrecht op toekomstige zaken dus een fluitje van een cent, het vestigen van een stil pandrecht op toekomstige vorderingen is ingewikkelder. Art. 3:239 lid 3 BW stelt namelijk een grens aan het reeds op het moment van het sluiten van de kredietovereenkomst kunnen verrichten van de vestigingshandeling: die is op dat moment slechts mogelijk voor zover de toekomstige vordering zal worden verkregen uit een dan reeds bestaande rechtsverhouding. Het is dus bijvoorbeeld niet mogelijk om dan reeds de handeling te verrichten die benodigd is voor het vestigen van een stil pandrecht op vorderingen die zullen voortkomen uit overeenkomsten met klanten die de kredietnemer-pandgever in de toekomst hoopt te acquireren. Anders dan voor wat betreft toekomstige roerende zaken zullen dus periodiek nieuwe (vervolg)pandaktes moeten worden opgemaakt en geregistreerd om deze 'supertoekomstige' vorderingen onder het stille pandrecht van de bank te krijgen, waarna - gelijk toekomstige zaken - het ontstaan van het pandrecht nog slechts afhangt van het al dan niet intreden van de beschikkingsbevoegdheid van de pandgever.

In de praktijk gaat het om miljoenen toekomstige vorderingen per jaar die in het kader van bancaire financieringen moeten worden verpand. Het in dat kader steeds moeten opmaken en registreren van een nieuwe akte voor elke vordering die ten tijde van het opmaken van de vorige akte nog niet voortkwam uit een reeds bestaande rechtsverhouding, is niet doenlijk. Vandaar dat er de laatste jaren enkele proefprocedures zijn gevoerd om te testen of een vereenvoudigde procedure daarvoor in overeenstemming is met de wettelijke vestigingsvereisten en inderdaad leidt tot een geldig pandrecht. Het ging daarbij om de wettelijke eis dat alle stil te verpanden vorderingen geregistreerd moeten zijn (art. 3:94 lid $3 \mathrm{BW}$ ), alsmede voldoende bepaald (art. 3:84 lid 2 jo. art. 3:98 BW). De praktijk bediende zich namelijk van één A4'tje als akte waarop slechts de eerste en de laatste stil te verpanden vorderingen werden vermeld en het totaalbedrag. Voor identificatie van de rest werd verwezen naar een computerlijst die zelf niet werd geregistreerd. Nadat de Hoge Raad in zijn arrest Stichting Spaarbank Rivierenland/Gispen q.q. bepaalde dat deze gang van zaken door de beugel kon, nu de wet niet de eis stelt dat de te verpanden vorderingen in de akte voldoende zijn bepaald, zolang maar door de akte, eventueel achteraf, kan worden bepaald om welke vorderingen het gaat, heeft de praktijk naar nog meer simplificering en standaardisering gezocht. ${ }^{15}$ Dit heeft uiteindelijk geleid tot de zogenaamde 'verzamelpandakte', die een algemene verpandingsclausule bevat die dagelijks wordt geregistreerd. Deze akte vermeldt niet langer expliciet de vorderingen waarvoor er wordt verpand, noch de vorderingen waarop het pandrecht ziet, noch de namen van de pandgevers. Met zijn arresten Dix q.q./ING en Van Leuveren q.q./ ING heeft de Hoge Raad de verzamelpandakte geaccordeerd, waarmee vaststaat dat deze vestigingsmethode inderdaad tot een geldig pandrecht leidt, mits natuurlijk aan de overige vestigingsvereisten is voldaan. ${ }^{16}$ Weliswaar is daarmee art. 3:239 lid $3 \mathrm{BW}$ behoorlijk uitgehold en betekent een en ander de facto de introductie van de Engelse floating charge in Nederland, maar daar staat tegenover dat deze methode een boel administratieve rompslomp en dus kosten bespaart, die anders zouden

15. HR 14 oktober 1994, ECLI:NL:HR:1994:ZC1488, NJ 1995/447 m.nt. W.M. Kleijn (Stichting Spaarbank Rivierenland/Gispen q.q.). Daarna leidde het arrest Mulder q.q./Rabobank tot een verdere versimpeling van de procedure (HR 20 september 2002, NJ 2002/184 m.nt. W.M. Kleijn). Vanaf dat moment werd in de (vervolg)pandakte volstaan met een generieke omschrijving van de te verpanden vorderingen (zonder vermelding van de NAW-gegevens van de debiteur van de eerste en laatste vordering en het totaalbedrag).

16. HR 3 februari 2012, NJ 2012/261 m.nt. F.M.J. Verstijlen (Dix q.q./ ING) en HR 1 februari 2013, NJ 2013/156 m.nt. F.M.J. Verstijlen (Van Leuveren q.q./ING). 
worden doorberekend aan de kredietnemer-pandgever. Hierbij dient in het achterhoofd te worden gehouden dat het bij uitstek de door de banken en factormaatschappijen verstrekte werkkapitaalfinancieringen zijn die bedrijven in de gelegenheid stellen met leverancierskrediet te werken, waarmee vorderingen ontstaan. Met de steeds verder vereenvoudigde verpandingsprocedure zijn de financieringskosten omlaaggegaan en dat is goed voor de economie in het algemeen en de bedrijfsfinanciering in het bijzonder.

\section{Ad 4. Kan het in zekerheid gegeven goed eenvoudig worden uitgewonnen?}

\section{Vorderingsrechten}

Het moge zo zijn dat met in de verzamelpandakte gebezigde vangnetclausules eenvoudig een stil pandrecht is te vestigen op vorderingen, de keerzijde ervan is dat de uitwinning van deze pandrechten er niet eenvoudiger op wordt. Uitwinning van vorderingen gebeurt immers normaliter door mededeling van het pandrecht aan de schuldenaar van de vordering, waarna de pandhouder de vordering int en zich uit het geïnde voldoet. Maar hoe weet je aan wie je mededeling moet doen, als in de verzamelpandakte gegevens ontbreken als de naam van de schuldenaar van de verpande vordering, het debiteur- en factuurnummer, enzovoort? Als die gegevens niet in de pandakte staan vermeld, zul je daarvoor inzage moeten hebben in de administratie van de pandgever en dus aangewezen zijn op zijn medewerking, of die van zijn curator als de pandgever inmiddels is gefailleerd. Zolang je die niet hebt, dreigt ook het gevaar dat schuldenaren uit eigener beweging nog aan de pandgever of curator betalen, of de curator actief de inning ter hand neemt. De inningsbevoegdheid van een stil verpande vordering blijft immers bij de pandgever of diens curator, zolang de pandhouder die niet naar zich toe heeft weten te trekken door van zijn pandrecht mededeling te doen aan de schuldenaar van de verpande vordering (art. 3:246 lid 1 BW).

Omdat de waarde van het pandrecht natuurlijk mede wordt bepaald door de uitwinbaarheid ervan, is het voor banken van groot belang zeker te zijn van de antwoorden op dit soort vragen. Daarover is dan ook regelmatig geprocedeerd en die antwoorden zijn er gekomen. Zo weten we (1) na het Rabo/Knol q.q.-arrest dat als een schuldenaar van een verpande vordering uit eigener beweging aan de pandgever betaalt, het pandrecht tenietgaat en de pandhouder geen recht heeft op afdracht, ${ }^{17}$ (2) na het Mulder q.q./CLBN-arrest dat dit anders is in faillissement, in die zin dat de pandhouder zijn voorrang behoudt op het door de curator geïnde, maar wel moet wachten tot het verbindend worden van de uitdelingslijst en moet meedelen in de algemene faillissementskosten, ${ }^{18}$ (3) eveneens na voornoemd Mulder q.q./CLBN-arrest dat verrekening door een bank mogelijk is ter zake van betalingen in het zicht van en tijdens faillissement, mits de vorderingen waarop de betalingen

17. HR 12 juli 2002, NJ 2003/194 m.nt. W.M. Kleijn (Rabo/Knol q.q.).

18. HR 17 februari 1995, NJ 1996/471 m.nt. W.M. Kleijn (Mulder q.q./ CLBN) binnenkomen aan de bank zijn verpand en ongeacht of de bank van die verpanding al dan niet mededeling heeft gedaan, ${ }^{19}$ (4) na het ING/Verdonk q.q.-arrest dat de curator, hoewel inningsbevoegd, twee weken lang pas op de plaats moet maken met innen teneinde de bank de gelegenheid te geven zich uit te laten over de vraag of zij tot uitoefening van haar pandrecht zal overgaan, ${ }^{20}$ en (5) na het Hamm q.q./ABN Amro-arrest dat de curator verplicht is de bank in staat te stellen de mededeling aan de schuldenaren van de verpande vorderingen te doen door haar inzage te geven in de administratie van de pandgever-failliet, dan wel haar tegen redelijke kosten die informatie te verstrekken. Bovendien werd met het laatste arrest duidelijk dat een actieve inning van de curator van de pandgever binnen voornoemde termijn van twee weken niet resulteert in een 'superboedelvordering' van de bank, maar in een boedelvordering met de aan haar pandrecht verbonden rang plus een concurrente boedelvordering voor de schade die zij door een dergelijk optreden van de curator heeft geleden, onverminderd de persoonlijke aansprakelijkheid van de curator voor dit gedrag indien daarvoor gronden zijn. ${ }^{21}$

\section{Roerende zaken}

Een pandrecht op roerende zaken wordt uitgewonnen door de verpande zaken te verkopen en zich te verhalen op de executieopbrengst (art. 3:248 BW). Omdat het in de regel om vuistloos pandrecht gaat, dient de pandhouder de verpande zaken daarvoor eerst in zijn macht te brengen. Daartoe kan hij afgifte aan hemzelf of aan een derde vorderen (art. 3:237 lid 3 BW). Gaat het bijvoorbeeld om een vuistloos verpande machine of een gehele productiestraat, dan levert de weg via afgifte zo goed als zeker niet de hoogste opbrengst op, waartoe de pandhouder jegens hemzelf, de pandgever en mogelijke andere pandhouders wel is gehouden. De machine of productiestraat zal daarvoor immers helemaal uit elkaar moeten worden gehaald, vervoerd, opgeslagen, enzovoort. Verstandiger is om in dergelijke gevallen de vuistloos verpande zaken direct vanuit het bedrijf van de kredietnemer-pandgever te verkopen. Daartoe wordt wel de zogenaamde bodemverhuurconstructie gebruikt. Niet alleen garandeert deze manier van invuistpandneming vrijwel altijd de hoogste verkoopopbrengst, maar tegelijkertijd worden de verpande zaken daarmee onvatbaar voor bodembeslag door de fiscus. Curatoren stelden zich wel op het standpunt dat het aangaan van een bodemverhuurconstructie, teneinde een vuistloos pandrecht om te zetten in een vuistpandrecht, paulianeus is. Zou de Hoge Raad die visie hebben gedeeld, dan was dat een aanmerkelijke inbreuk geweest op de dekkingswaarde van het pandrecht op dergelijke zaken. Hij volgt echter een andere weg: de omzetting van een vuistloos pandrecht in een vuistpand via een bodemverhuurconstructie moet worden gekwalificeerd als een feitelijke handeling die

19. HR 17 februari 1995, NJ 1996/471 m.nt. W.M. Kleijn (Mulder q.q./ CLBN), r.o. 3.5.

20. HR 22 juni 2006, NJ 2007/520 m.nt. P. van Schilfgaarde (ING/Verdonk q.q.).

21. HR 30 oktober 2009, NJ 2010/95 m.nt. F.M.J. Verstijlen (Hamm q.q./ ABN Amro). 
buiten het bereik van art. $42 \mathrm{Fw}$ valt, aangezien alleen rechtshandelingen paulianeus kunnen zijn. ${ }^{22}$

Was volgens de Hoge Raad dus met de bodemverhuurconstructie niets mis, de fiscus heeft het daarbij niet laten zitten. Het kort ervoor ingevoerde artikel 22bis van de Invorderingswet 1990 heeft de financierbaarheid van inventaris behoorlijk beperkt en is zelfs voor de Wereldbank aanleiding geweest om in haar rapport 'Doing Business 2014' op pagina 167 op te merken:

'The Netherlands weakened its secured transaction system through an amendment to the Collection of State Taxes Act that grants priority outside bankruptcy to tax claims over secured creditors' claims.'

Ons inziens is dit geen goede ontwikkeling voor de financierbaarheid van het bedrijfsleven.

In onze bijdrage 'Uitoefening van goederenrechtelijke zekerheidsrechten in de (bank)praktijk' uit 2009 aan dit Maandblad lieten wij zien dat binnen de financiële praktijk zich enkele varianten voor de uitoefening van goederenrechtelijke zekerheidsrechten hebben ontwikkeld die minder tijd en geld kosten en meer opbrengen dan de standaardroute van openbare verkoop door de pandhouder. ${ }^{23}$ Voorzichtigheid daarbij was echter geboden. De tijd heeft niet stilgestaan. De recente crisis heeft onder meer de retailsector hard getroffen. In deze sector zal, afgezet tegen verkoop aan een enkele partij of opkoper, een (opheffings)uitverkoop borg staan voor een substantieel hogere verkoopopbrengst van de verpande (winkel)voorraad. Met het arrest van de Hoge Raad van 14 februari 2014 (Feenstra q.q./ING) is duidelijk geworden dat een tussen zekerheidsgever (of diens curator) en zekerheidsnemer overeengekomen verkoop door de zekerheidsgever, die niet ter toetsing aan de rechter is voorgelegd, in en buiten faillissement kwalificeert als een executoriale verkoop, mits partijen daartoe de bedoeling hebben en er sprake is van verzuim. ${ }^{24}$ De uitwinbaarheid van pandrechten op dit soort roerende zaken is daarmee een stuk gemakkelijker en zekerder geworden, hetgeen de financieringspraktijk ten goede komt.

Een en ander is namelijk mede van belang voor het leerstuk van verrekening. Omdat de bijschrijving van de opbrengst van de executieverkoop op de door de pandgever bij de bank aangehouden rekening volgens de Hoge Raad nog onderdeel uit-

22. HR 21 juni 2013, NJ 2014/272 m.nt. H.J. Snijders (Eringa q.q./ABN Amro).

23. R. van den Bosch \& F.E.J. Beekhoven van den Boezem, Uitoefening van goederenrechtelijke zekerheidsrechten in de (bank)praktijk, MvV 2009, p. $85-94$.

24. HR 14 februari 2014, ECLI:NL:HR:2014:319, JOR 2014/118 m.nt. B.A. Schuijling (Feenstra q.q./ING). Zie over (de impact van) dit arrest uitgebreid F.E.J. Beekhoven van den Boezem \& G.J.L. Bergervoet, Onderhandse verkoop, executie en verrekening, in: F.E.J. Beekhoven van den Boezem, G.J.L. Bergervoet \& F.M.J. Verstijlen (red.), Groninger zekerheid: liber amicorum Wim Reehuis, Deventer: Kluwer 2014, p. 9-25. maakt van de executoriale verkoop, hoeven de 'tips' die hij in zijn arrest ING/Gunning q.q. gaf om als bank op die manier te mogen 'verrekenen' - te weten: verpanding van de vordering tot betaling van de koopprijs en rechtstreekse betaling aan de bank - niet van stal te worden gehaald. ${ }^{25}$ Van verrekening in de zin van art. 6:140 BW is immers volgens de Hoge Raad in dit geval überhaupt geen sprake. Voor de praktijk is dit van groot belang, omdat verpanding van de vordering tot betaling van de koopprijs niet goed denkbaar is wanneer het bijvoorbeeld gaat om een door pandhouder en pandgever overeengekomen executieverkoop in de vorm van een door de pandgever te realiseren opheffingsuitverkoop van een kledingzaak. De momenten waarop de rechtsverhouding waaruit de vordering tot betaling van de koopprijs van een kledingstuk ontstaat, waarop deze vordering zelf ontstaat, en waarop zij weer tenietgaat door contante of pinbetaling, vallen immers vrijwel samen. Zelfs het gebruikmaken van de verzamelpandakte zou aan dit probleem niet tegemoetkomen.

\section{Registergoederen}

Uit het Motorpassagiersschip-arrest van de Hoge Raad lijkt te volgen dat ook buiten faillissement een onderhandse verkoop van een met hypotheek bezwaard goed, die niet aan de rechter is voorgelegd, onder de omstandigheden zoals in de zaak ING/ Feenstra q.q. eveneens als een executoriale verkoop kan worden aangemerkt. ${ }^{26}$ Naar onze mening is dit een vergissing van de Hoge Raad, is deze beslissing zelfs contra legem, en kan een onderhandse verkoop die niet voldoet aan de eisen van art. 3:268 lid 2 BW, buiten faillissement nimmer worden gekwalificeerd als een executoriale verkoop. Daaraan staat art. 3:268 lid $5 \mathrm{BW}$ in de weg. Het kan toch niet de bedoeling van de Hoge Raad zijn geweest dat hypotheekhouder en hypotheekgever buiten de rechter om een onderhandse verkoop kunnen entameren die tot zuivering leidt (art. 3:273 BW), waardoor andere belanghebbenden als beslagleggers en overige hypotheekhouders volledig buiten spel worden gezet? En als een dergelijke verkoop toch wél een executieverkoop zou zijn, waartoe dienen dan voornoemde 'verrekentips' die de Hoge Raad gaf in de zaak ING/Gunning q.q.? Indien het om executie zou gaan, kom je immers niet aan verrekening toe, ook niet als de verkoopopbrengst op de rekening van de zekerheidsgever bij de bank wordt geboekt. Kortom: wil een bank omwille van een maximale verkoopopbrengst een verhypothekeerde zaak zonder rechterlijke bemoeienis onderhands verkopen, en de verkoopopbrengst boeken op de rekening die de klant bij de bank aanhoudt, dan zal (1) de vordering tot betaling van de koopprijs aan de bank moeten worden verpand, dan wel (2) evident moeten zijn dat de boeking van de verkoopopbrengst op de rekening die de klant bij de bank aanhoudt desalniettemin heeft te gelden als een betaling aan de bank, ${ }^{27}$ willen de

25. HR 19 november 2004, NJ 2005/199 m.nt. P. v. Schilfgaarde (ING/ Gunning q.q.).

26. HR 15 maart 2013, ECLI:NL:HR:2013:BZ4072, TvI 2013/23 m.nt. A van Eijsden (Motorpassagiersschip).

27. Dat het dan wel goed gaat, blijkt uit Hof Amsterdam 7 december 2010 JOR 2011/99 (ING/Savelkoul q.q.) 


\section{Maandblad \\ Vermogensrecht}

strenge verrekenregels waarover wij in onze bijdrage uit 2009 schreven, niet van toepassing zijn. Naar aanleiding van het arrest ING/Gunning q.q. is bij ING voor alle zekerheid de praktijk ingevoerd dat bij dergelijke onderhandse trajecten eerst op een speciale rekening van ING zélf wordt betaald, waarna de opbrengst direct wordt doorgeboekt naar de debet staande rekening van de kredietnemer. Dit is een aan de praktijk moeilijk uit te leggen extra logistieke handeling: iedereen zal het er toch over eens zijn dat uiteindelijk de verkoopopbrengst moet worden geboekt op de debet staande kredietrekening van de kredietnemer.

\section{Conclusie}

In deze bijdrage hebben wij enkele gerechtelijke procedures besproken die voor banken van belang waren om erachter te komen of bepaalde goederenrechtelijke zekerheden (voldoende) dekkingswaarde bieden. Dat deze dekkingswaarde van cruciaal belang is bij de afwikkeling na verzuim aan de zijde van de kredietnemer, spreekt voor zich. Het is echter van even groot belang om in- en extern te kunnen verantwoorden dat voor de lening waarop de zekerheden zien, minder kapitaal wordt aangehouden dan zonder die zekerheden het geval zou zijn. Gelet op het grote belang van deze problematiek voor het kapitaalsbeslag, en het feit dat nog lang niet alle vragen daarover zijn beantwoord, zullen daar de komende jaren nog wel wat procedures bij komen. Zo wordt bijvoorbeeld op dit moment een proefprocedure gevoerd over de vraag naar de verpandbaarheid van roerende zaken die onder eigendomsvoorbehoud zijn geleverd. Als een kredietnemer te maken heeft met leveranciers die zich van een uitgebreid eigendomsvoorbehoud bedienen, dan is daarmee mogelijk een tijdbom onder het pandrecht van de bank geplaatst. Zelfs als de leveranciers bij een faillissement van de kredietnemer maar een geringe restvordering hebben, dan is op de geleverde en wel betaalde goederen geen pandrecht tot stand gekomen, zo de visie van het Hof Den Haag wordt gevolgd. ${ }^{28}$ Dergelijke onzekerheden plaatsen banken voor grote dilemma's in hun financieringsstrategie. Wat heb je immers aan een pandrecht als het niet zeker is dat het is gevestigd, of het niet of moeilijk uitwinbaar is? Wat daarvan ook zij, soms kan een gang naar de rechter niet het benodigde comfort geven en dient de wetgever met oplossingen te komen teneinde de financierbaarheid van het bedrijfsleven te (blijven) garanderen. Gedacht kan worden aan het afschaffen van de goederenrechtelijke werking van onoverdraagbaarheids- en onverpandbaarheidsbedingen, ${ }^{29}$ het invoeren van een elektronische registratiemogelijkheid voor pandakten ${ }^{30}$ en het creëren van de mogelijkheid van een onderhandse executoriale verkoop van een met hypotheek bezwaard

28. Hof Den Haag 2 september 2014, JOR 2015/53 m.nt. W.J.M. van Andel en M.E. ten Brinke (Rabobank/Reuser q.q.).

29. Zie daarover F.E.J. Beekhoven van den Boezem, Recht- en forumshopping in de bedrijfsfinancieringspraktijk bezien vanuit Nederlands perspectief, in: Forumshopping (Preadviezen Nederlandse Vereniging voor Burgerlijk Recht 2014), Zutphen: Uitgeverij Paris 2014, p. 52-57.

30. Zie daarover F.E.J. Beekhoven van den Boezem, Onderhandse pandakten in het licht van het elektronisch verkeer: nog één horde te nemen, TvI 2011, p. 65-68. goed waarbij de belangen van alle betrokkenen voldoende zijn gewaarborgd..$^{31}$ Benieuwd wat daarover allemaal is te melden bij het volgende lustrum van het Maandblad voor Vermogensrecht!
31. Zie daarover I. Visser, De executoriale verkoop van onroerende zaken door de hypotheekhouder (diss. Groningen), Den Haag: Boom Juridische uitgevers 2013, p. 433 en 437, J.H.S.G.K. Timmermans \& M. van Wingerden, Onderhandse executie bij hypotheek op woonhuizen, in: Liber amicorum Mart Franken, 2013, p. 147-155, <www.vil.nl/nl/ liberamicorum $>$ en P.A. Stein, Onderhandse verkoop van hypothecair bezwaarde goederen, in: A.A. van Velten e.a. (red.), 85 jaar Nederlandse Vereniging van Nederlandse Hypotheekbanken (feestbundel), Deventer: Kluwer 1991. 